\title{
Design and Development of Stand-Alone Renewable Energy based Hybrid Power System for Remote Base Transceiver Station
}

\author{
Priyanka Anand \\ Department of Electrical \\ Engineering \\ I.K.G. Punjab Technical \\ University \\ Kapurthala, Punjab, India
}

\author{
Sarbjeet Kaur Bath \\ Department of Electrical \\ Engineering \\ G. Z.S. Campus College of \\ Engineering \& Technology \\ Bathinda, India
}

\author{
Mohammad Rizwan \\ Department of Electrical \\ Engineering \\ Delhi Technological University \\ Delhi, India
}

\begin{abstract}
Due to the increasing number of mobile users, there is a huge demand of Base Transceiver Station (BTS) particularly in rural and semi urban areas. These BTS are operated on diesel generator (DG) and also connected with the existing grid supply. However, the grid supply is rarely available in most of the remote locations. Therefore, diesel generators are mainly used for providing the continuous supply to BTS and causes lot of emissions.

In view of the above problems, a renewable energy based hybrid power system is proposed to fulfill the requirement of BTS. In this work, a hybrid model based on solar photovoltaic (SPV)/battery/diesel generator (DG) set is proposed for remote BTS application using HOMER (Hybrid Optimization Model for Electric Renewable) software. Further, technoeconomic analysis with environmental benefits has been done and presented in this paper. In addition, sensitivity analysis has been performed for the proposed model. The proposed model gives reduced cost of energy (COE) of $\$ 0.217$ as compared to $\$ 0.266$ of the existing diesel generator system. Also, the reduction in $\mathrm{CO}_{2}, \mathrm{CO} \mathrm{UHC}, \mathrm{PM}, \mathrm{SO}_{\mathrm{x}}$ and $\mathrm{NO}_{\mathrm{x}}$ emission is $17.138,0.419,0.0473,0.0318,0.344,3.78$ tonnes per year respectively.
\end{abstract}

\section{General Terms}

Solar Energy, Diesel Generator, Hybrid System, HOMER.

\section{Keywords}

Renewable energy, solar photovoltaic, HOMER, greenhouse gas emissions.

\section{INTRODUCTION}

The demand of electrical energy is increasing drastically due to rapid industrialization, inventions in new technologies, urbanization and increasing household consumptions etc. However, the power generated from the conventional sources is becoming costly due to the rising prices of fossil fuels and their depletion. Further, a large number of the population of India lives in villages and majority of villages are far from the utility grid. In India, especially small villages in the remote areas have no access of electrical energy or it is limited to a few hours. The electricity from diesel generator (DG) is not a feasible solution due to its fuel cost, transportation and maintenance cost and greenhouse gas (GHG) emissions etc. To provide reliable and cost-effective power supply in remote locations is still challenging [1]. In order to meet these challenges, power generation through renewable energy sources can become a sustainable and environmental friendly alternative in near future. Major types of renewable energy sources such as solar, wind, biogas and small hydro have huge potential to generate power on large extent. In addition, to promote power generation through renewable energy, Government of India has taken many initiatives and fixed a target of adding $175 \mathrm{GW}$ power generation from renewable energy resources by 2022 . The capacity addition from different renewable energy sources includes solar energy, wind energy, bio-power and small hydro is $100 \mathrm{GW}, 60 \mathrm{GW}$, $10 \mathrm{GW}$ and $5 \mathrm{GW}$ respectively [2].

However, there are certain drawbacks of renewable energy resources like intermittent nature, dependency on climatic condition that make the system design unreliable and is not sufficient to meet the demand for long periods. For enhancing the reliability of the system the energy storage and/or additional sources are required for backup purpose that causes the increase in the cost of the system which is undesirable. Renewable energy based hybrid system could be a good option for electrification of remote rural areas where grid extension is difficult and not economical [3-6]. It can also deal with limitations in terms of efficiency, fuel flexibility, reliability, economics and emissions. There are several configurations available in the literature like solar photovoltaic (SPV)/hydro/DG hybrid system, SPV/wind/battery/DG hybrid system, SPV/wind/battery hybrid system, SPV/wind hybrid system, SPV/biomass hybrid system, wind/biomass hybrid system etc. which are used for electrification in rural areas [3-29].

Base Transceiver Stations (BTS) are considered as the primary source of energy consumption, which requires a continuous supply of power for its efficient operation. Providing dedicated reliable and cost-effective power supply to BTS in India is a challenging task as most of the remote areas are still not connected to the grid. As a result, most of the mobile towers operate on diesel generators which cause high operational cost, poor service and huge environmental pollution in the form of $\mathrm{SO}_{\mathrm{x}}, \mathrm{NO}_{\mathrm{x}}$ and other carbon emissions. The government has already taken many initiatives to reduce the pollution caused by various power plants. Combining diesel generator with renewable energy could be a viable solution to mitigate these problems.

Number of papers has been published in the literature related to a hybrid power system. Some of the recent research work [11-22] is described in this paper. These models include $\mathrm{SPV} /$ supercapacitors for telecom network in Australia [11], $\mathrm{SPV} /$ proton-exchange membrane fuel cell to power remote repeater station in California [12], SPV/battery, SPV/fuel cell, SPV/fuel cell/battery [13], SPV/wind hybrid power systems along with DG for cellular mobile telephone station in India 
[14], SPV/Biomass hybrid system for rural area [15], SPV/wind hybrid system to power GSM/CDMA type mobile base station for Bhopal, India [16], wind/SPV/battery [17] for remote telecom station of Nepal, SPV/wind for rural region of Cango [18], SPV/hydro/DG system [19], SPV/DG hybrid system for Nigeria [20], techno-economic and environmental performance of various hybrid systems using HOMER [21], $\mathrm{SPV} /$ wind energy based hybrid model for BTS in Nigeria [22] etc.

From above literature, it is observed that a hybrid model for BTS is rarely available in India particularly in Haryana state, India. In view of the above, a case study of remote Base Transceiver Station (BTS) of village Khanpur Kalan, district Sonipat, state Haryana has been selected in this paper. A hybrid model based on SPV, battery, DG has been proposed to fulfill the electricity requirement of remote BTS. The proposed model is developed using HOMER software as discussed in the following sections.

\section{DEVELOPMENT of HYBRID MODEL for BTS APPLICATION}

Feasibility study and analysis of hybrid model on the basis of the availability and potential of renewable energy in the rural village Khanpur Kalan (29.00 N latitude and 76.99 E longitude) in Sonipat district of Haryana state, India has been done and presented in this paper. In this work, a hybrid model consisting of SPV system along with a DG set and battery has been proposed and shown in Figure 1.

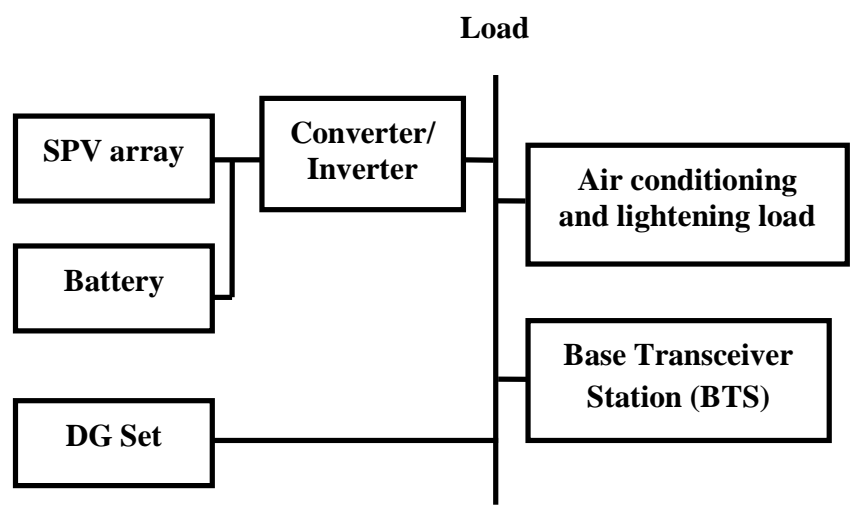

Fig. 1. Block diagram of hybrid model for BTS application

Hybrid Optimization Model for Electrical Renewable (HOMER) software developed at National Renewable Energy Laboratory (NREL) has been used for simulation and optimization purpose [30]. Using HOMER software, simulation of various renewable energy based power system configurations with all the combinations of the components have been done by providing various inputs such as solar irradiance data, hourly load, size and cost of components, etc. It performs several of hourly simulations in order to obtain the best possible match of the supply with the demand. HOMER rejects all infeasible combinations and scales the feasible systems on the basis of net present cost (NPC). A flowchart of the HOMER approach for the development of hybrid model is illustrated in Figure. 2.

The details of various parameters such as renewable energy resource i.e solar energy potential of the area, load profile of the BTS and description of size, cost and other parameters of SPV array, battery, converter, DG etc. in the proposed model have been described in the following sections.

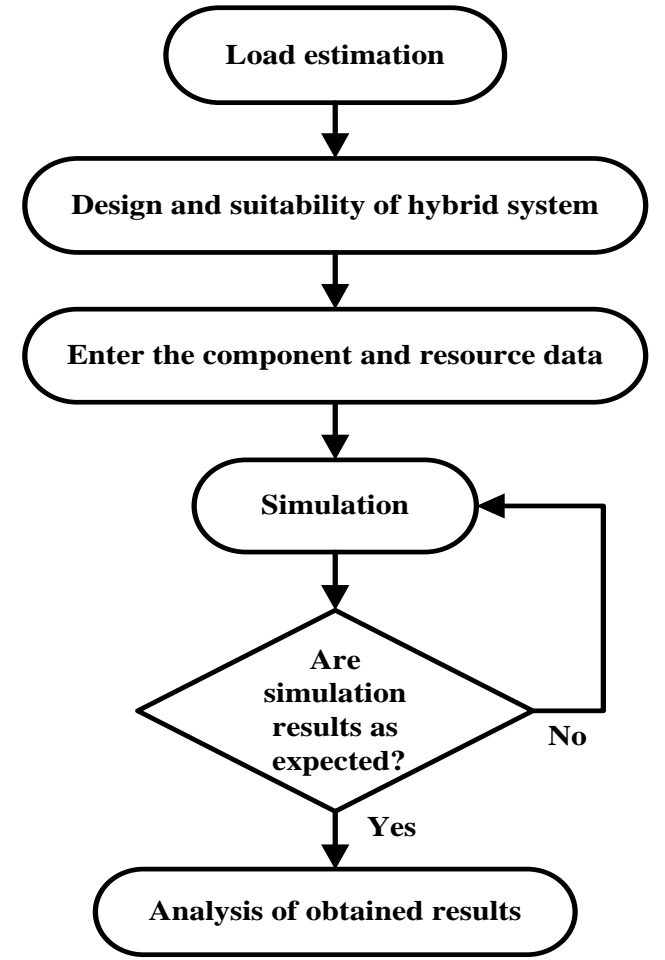

Fig. 2. Flowchart for the design of hybrid power system

\subsection{Potential of Solar Energy Resource at Proposed Site}

Before designing and development of hybrid model at particular site, it is necessary to identify the availability and potential of solar energy. Therefore, the solar irradiance data for the various months of the year have been obtained by HOMER software for the proposed site based upon its longitude $(76.99 \mathrm{E})$ and latitude $(29.00 \mathrm{~N})$ and is shown in Table 1.

Table 1. Solar irradiance data of Khanpur Kalan, Haryana, India

\begin{tabular}{|c|c|c|}
\hline Month & $\begin{array}{c}\text { Clearness } \\
\text { Index }\end{array}$ & $\begin{array}{c}\text { Solar Irradiance } \\
\left(\mathbf{k W h} / \mathbf{m}^{2} / \mathbf{d a y}\right)\end{array}$ \\
\hline January & 0.615 & 3.742 \\
\hline February & 0.624 & 4.553 \\
\hline March & 0.629 & 5.57 \\
\hline April & 0.621 & 6.375 \\
\hline May & 0.607 & 6.738 \\
\hline June & 0.595 & 6.77 \\
\hline July & 0.543 & 6.091 \\
\hline August & 0.539 & 5.678 \\
\hline September & 0.635 & 5.911 \\
\hline October & 0.656 & 5.077 \\
\hline November & 0.643 & 4.076 \\
\hline December & 0.605 & 3.442 \\
\hline Average & 0.605 & 5.34 \\
\hline
\end{tabular}

From Table 1, it is observed that an annual average global solar irradiance is $5.34 \mathrm{kWh} / \mathrm{m}^{2} /$ day. It is also revealed the maximum solar irradiance is $6.77 \mathrm{kWh} / \mathrm{m}^{2} /$ day in the month 
of June and minimum solar irradiance is $3.442 \mathrm{kWh} / \mathrm{m}^{2} /$ day in the month of December.

\subsection{Connected Load}

Generally, a BTS site load includes BTS components and equipment load with air-conditioning and lighting load. In this work, the estimated annual peak load of the proposed site is $6.3 \mathrm{~kW}$ with an average of $151 \mathrm{kWh} /$ day. It is anticipated that the load is identical for every day of the year.

\subsection{Cost, Size and Other Parameters of Hybrid System Components}

The capital cost, replacement cost and operation and maintenance $(\mathrm{O} \& \mathrm{M})$ costs play a significant role in determining the optimal size of any hybrid system. The capital cost is the initial investment cost of the component. Replacement cost is the cost of replacing that component with a new one at the end of lifetime of the old one, whereas the operation and maintenance (O\&M) cost is the annual cost incurred for the operation and maintenance of the components [30].

Further, in order to get the optimal system, the different sizes of selected components of the proposed hybrid model i.e SPV system, DG, converter and battery has been given as an input in their respective input window in HOMER. The size of components of the proposed hybrid model has been chosen and cost has been estimated and presented in Table 2 .

Table 2. Costs and size of components of the proposed hybrid model

\begin{tabular}{|c|c|c|c|c|}
\hline Item & Capital Cost (\$) & $\begin{array}{c}\text { Replacement } \\
\text { Cost } \mathbf{( \$ )}\end{array}$ & O\&M Cost & Considered Size \\
\hline SPV array (1 kW) & 1000 & 0 & $1 \$ /$ year & $0,5,10,15,19,24 \mathrm{~kW}$ \\
\hline $10 \mathrm{KVA}$ diesel generator & 610 & 0 & $0.1 \$ /$ hour & $0,7 \mathrm{~kW}$ \\
\hline Converter $(7 \mathrm{~kW})$ & 230 & 230 & $1 \$ /$ year & $0,7,8,9 \mathrm{~kW}$ \\
\hline Battery (vision 6FM200D) & $150 /$ battery & $100 /$ battery & $100 \$ /$ year & $0,3,5,7,9,10(\mathrm{no})$. \\
\hline
\end{tabular}

The various parameters other than cost and size of components of the proposed hybrid model were also taken in to consideration are enumerated below.

The lifetime of the SPV array is considered to be 25 years. The derating factor is assumed to be $80 \%$, which accounts for the reduction of output of SPV array due to the various effects such as dust on the panel, elevated temperature, wire losses etc. [19]. The ground reflectance is the portion of incident solar radiation reflected by the ground, is considered to be 20 $\%$ [19]. No tracking system is considered in the SPV system.

The lifespan of the DG is considered as 20000 hours [19]. The minimum load ratio is a minimum amount of allowable load on the diesel generator as a percentage of its rated capacity, is set to be $30 \%$ [19]. The cost of diesel fuel also plays an essential role in designing a hybrid power system. In this study, the cost of diesel is taken as $\$ 0.75$ per litre. Intercept coefficient (ratio of no-load fuel consumption of the diesel generator to its rated capacity) is $0.08 \mathrm{~L} / \mathrm{hr} / \mathrm{kW}$ and slope is marginal fuel consumption of the diesel generator, is assumed to be $0.25 \mathrm{~L} / \mathrm{hr} / \mathrm{kW}$ [19]. The heat recovery ratio is not considered in this study.

Converter can work both as an inverter and rectifier on the basis of direction of flow of power. Inverter is used to provide power from the SPV system or battery to the load while the rectifier can be used to store the surplus power from the diesel generator to the battery. The lifetime of an inverter is taken as 20 years with an efficiency of $95 \%$.

The battery is a storage device that has two operating modes i.e charging and discharging. Excess energy from SPV system can be stored and used to deliver for the duration of night time or during load shedding hours. The vision 6FM200D battery has been chosen for the proposed system.

\subsection{Economic, Constraint and System Control Inputs}

The various economic and constraints inputs such as project lifetime, annual rate of interest, operating reserve etc. were provided as the input information required by the simulation model. The expected project lifetime has been assumed to be 25 years with an annual rate of interest of $9 \%$. The penalty for any capacity shortage has not been considered in the system. There is no capacity shortage for the proposed system and an operating reserve of $10 \%$ of hourly load is considered to accounts for the unexpected increase in load. Furthermore, the operating reserve of $25 \%$ as a percentage of solar power output has been considered for the proposed system to account for an abrupt decrease in output of SPV array. Operating reserve is basically the safety margin that facilitates to make sure the reliability of the supply in spite of unpredictability in hourly load and solar power output.

In system control input, there are two types of dispatch strategies which are load following and cycle charging. In the load following strategy, whenever DG is needed, then it would generate only that much power which is necessary for accomplishing the load demand. While, in the cycle charging strategy, at whatever time a DG is required for operation, it works at full capacity with excess power used to charge the battery bank [30]. In addition to this strategy, a setpoint state of charge can also be applied, in which the generator does not stop charging the battery until the defined state of charge is achieved. In the present work, cycle charging strategy along with $80 \%$ setpoint state of charge is considered [19].

\section{SIMULATION RESULT and DISCUSSION}

Depending upon the availability, different sources like SPV system, battery, DG set has been selected for the proposed site. Using these sources, the feasibility analysis of various configurations has been done. These configurations include DG set only, DG set with battery, SPV/DG set without battery and SPV/DG set with battery.

Techno-economic analysis of all the above mentioned configurations has been done on the basis of net present cost (NPC), cost of energy (COE) and greenhouse gas (GHG) emissions using HOMER software. The layout of the developed hybrid model is presented in Figure. 3. 


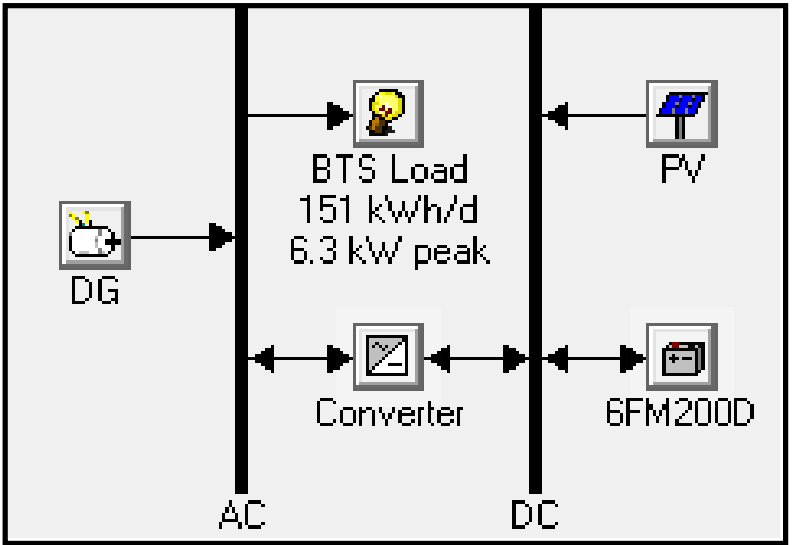

Fig. 3. Layout of the developed hybrid model using HOMER

\subsection{Techno-economic and GHG Emissions Analysis}

Techno-economic analysis of all the configurations has been done to evaluate the performance of the developed models. Based on the COE and GHG emissions, a suitable model has been selected for the proposed site. By providing the components inputs in HOMER software, simulations of various configurations have been performed on the basis of NPC and an optimized model has been selected. Result of the possible configurations with their rating is presented in Table 3.
Table 3. Various ratings of possible configurations

\begin{tabular}{|c|c|c|c|c|}
\hline Configuration & $\begin{array}{c}\text { PV } \\
(\mathbf{k W})\end{array}$ & $\begin{array}{c}\text { DG } \\
(\mathbf{k W})\end{array}$ & $\begin{array}{c}\text { Battery } \\
(\mathbf{n o .})\end{array}$ & $\begin{array}{c}\text { Converter } \\
(\mathbf{k W})\end{array}$ \\
\hline DG set only & -- & 7 & -- & -- \\
\hline $\begin{array}{c}\text { DG set with } \\
\text { battery }\end{array}$ & -- & 7 & 3 & 1 \\
\hline $\begin{array}{c}\text { SPV/DG set } \\
\text { without battery }\end{array}$ & 24 & 7 & -- & 7 \\
\hline $\begin{array}{c}\text { SPV/DG set } \\
\text { with battery }\end{array}$ & 19 & 7 & 3 & 7 \\
\hline
\end{tabular}

Further, a comparison of all the four possible configurations has been done in terms of initial capital, NPC, annualized cost, COE etc. and is presented in the Table 4.

From Table 4, it is observed that the NPC of SPV/DG set with battery is $\$ 117599$ whereas it is \$ 123942 of SPV/DG set without battery, \$ 144090 for DG set only and \$ 147689 for DG set with battery. In addition, the COE of SPV/DG set with battery is $\$ 0.217$ whereas it is $\$ 0.229 / \mathrm{kWh}, \$ 0.266 / \mathrm{kWh}, \$$ $0.273 / \mathrm{kWh}$ for SPV/DG set without battery, DG set only and DG set with battery respectively. Moreover, the configuration SPV/DG set with battery has least fuel consumption and hours of operation of DG set than SPV/DG set without battery, DG set only and DG set with battery. SPV/DG set with battery hybrid model is still the better option on the basis of economic point of view.

In addition, the contribution of individual components in the NPC in SPV/DG set with battery hybrid model is given in the Table 5.

Table 4. Various cost associated with different configurations

\begin{tabular}{|c|c|c|c|c|c|c|c|c|}
\hline Configuration & $\begin{array}{c}\text { Initial } \\
\text { Capital } \\
\text { Cost }(\$)\end{array}$ & $\begin{array}{c}\text { Operating } \\
\text { Cost } \\
\text { (\$/year) }\end{array}$ & $\begin{array}{l}\text { NPC } \\
(\$)\end{array}$ & $\begin{array}{c}\text { Annualized } \\
\text { Cost } \\
\text { (\$/year) }\end{array}$ & $\begin{array}{c}\text { COE } \\
(\$ / k W h)\end{array}$ & $\begin{array}{c}\text { Fuel } \\
\text { Consumption } \\
\text { (litre) }\end{array}$ & $\begin{array}{c}\begin{array}{c}\text { Hours of } \\
\text { Operation } \\
\text { of DG Set } \\
\text { (hour/year) }\end{array} \\
\end{array}$ & $\begin{array}{c}\text { Renewable } \\
\text { Fraction }\end{array}$ \\
\hline DG set only & 427 & 14626 & 144090 & 14669 & 0.266 & 18683 & 8760 & 0.00 \\
\hline $\begin{array}{l}\text { DG set with } \\
\text { battery }\end{array}$ & 910 & 14943 & 147689 & 15036 & 0.273 & 18684 & 8760 & 0.00 \\
\hline $\begin{array}{l}\text { SPV/DG set } \\
\text { without battery }\end{array}$ & 24657 & 10108 & 123942 & 12618 & 0.229 & 12796 & 6914 & 0.51 \\
\hline $\begin{array}{l}\text { SPV/DG set } \\
\text { with battery }\end{array}$ & 20107 & 9925 & 117599 & 11972 & 0.217 & 12175 & 6116 & 0.46 \\
\hline
\end{tabular}

Table 5. Share of individual components in the NPC in hybrid SPV/DG set with battery system

\begin{tabular}{|c|c|c|c|c|c|c|}
\hline Component & $\begin{array}{c}\text { Capital Cost } \\
(\mathbf{\$})\end{array}$ & $\begin{array}{c}\text { Replacement } \\
\text { Cost } \mathbf{( \$ )}\end{array}$ & $\begin{array}{c}\text { O\&M Cost } \\
\mathbf{( \$ )}\end{array}$ & Fuel Cost (\$) & $\begin{array}{c}\text { Salvage } \\
\text { Value (\$) }\end{array}$ & Total (\$) \\
\hline SPV array & 19000 & 0 & 187 & 0 & 0 & 19187 \\
\hline DG & 427 & 0 & 4205 & 89695 & 0 & 94327 \\
\hline $\begin{array}{c}\text { Vision } \\
\text { 6FM200D }\end{array}$ & 450 & 437 & 2947 & 0 & -9 & 3825 \\
\hline Converter & 230 & 41 & 10 & 0 & -20 & 261 \\
\hline System & 20107 & 478 & 7348 & 89695 & -29 & 117599 \\
\hline
\end{tabular}


Further, in order to evaluate the economic measures in terms of present value of fuel saved, annual worth, return on investment, payback etc., a comparison has been made in between SPV/DG set with battery hybrid system and DG set only system using HOMER. A DG set only system was selected as base case system and SPV/DG set with battery hybrid system was considered as current system. The result of the economic measures comparison of the SPV/DG set with battery hybrid system and DG set only system are illustrated in Table 6.

Table 6. Economic measures of SPV/DG set with battery hybrid system and DG set only system

\begin{tabular}{|c|c|}
\hline Economic Measures & Value \\
\hline Present worth & $\$ 26490$ \\
\hline Annual worth & $\$ 2697 /$ year \\
\hline Return on investment & $23.9 \%$ \\
\hline Internal rate of return (IRR) & $23.8 \%$ \\
\hline Simple payback & 4.63 years \\
\hline Discount payback & 5.63 years \\
\hline
\end{tabular}

It is revealed from Table 6 that the present worth i.e the difference between the NPC of SPV/DG set with battery hybrid system and DG set only system is $\$ 26490$. A positive sign shows that the SPV/DG set with battery hybrid system saves money over the project lifetime compared to DG set only system. Payback is 4.63 years which is a sign of how much time it takes to recover the difference in investment costs between the current system and base case system.

Greenhouse gas emissions analysis is also carried out for all the four possible configurations and presented in Table 7.

From Table 7, it is observed that the configuration of SPV/DG set with battery has least GHG emissions as compared to the SPV/DG set without battery, DG set only and DG set with battery. Therefore, it is concluded in terms of least emission that the hybrid SPV/DG set with battery is found better as compared to SPV/DG set without battery, DG set only and DG set with battery. Moreover, SPV/DG set with battery system has least NPC and COE than the SPV/DG set without battery, DG set only and DG set with battery. Hence, the hybrid SPV/DG set with battery model is proposed because of lesser NPC, lesser COE and smaller amount of GHG emission.

Table 7. Greenhouse gas emissions of different configurations

\begin{tabular}{|c|c|c|c|c|}
\hline Pollutant emission & DG Set Only & $\begin{array}{c}\text { DG Set With } \\
\text { Battery }\end{array}$ & $\begin{array}{c}\text { SPV/DG Set } \\
\text { Without Battery }\end{array}$ & $\begin{array}{c}\text { SPV/DG Set } \\
\text { With Battery }\end{array}$ \\
\hline Carbon dioxide (CO $)$ emission (tonnes/year) & 49.200 & 49.200 & 33.695 & 32.062 \\
\hline Carbon monoxide (CO) emission (tonnes/year) & 1.21 & 1.21 & 0.832 & 0.791 \\
\hline $\begin{array}{c}\text { Unburned hydrocarbons (UHC) emission } \\
\text { (tonnes/year) }\end{array}$ & 0.135 & 0.135 & 0.0921 & 0.0877 \\
\hline $\begin{array}{c}\text { Particular matter (PM) (tonnes/year) } \\
\text { Sulphur oxide (SO }) \text { (tonnes/year) }\end{array}$ & 0.0915 & 0.0916 & 0.0627 & 0.0597 \\
\hline Nitrogen oxide $\left(\mathrm{NO}_{\mathrm{x}}\right.$ ) (tonnes/year) & 10.84 & 10.84 & 0.677 & 0.644 \\
\hline
\end{tabular}

\subsection{Energy Production Analysis}

The excess electricity and capacity shortage from various configurations i.e DG set only, DG set with battery, SPV/DG set without battery and SPV/DG set with battery is presented in Table 8 .

Table 8. Excess electricity and capacity shortage of various configurations

\begin{tabular}{|c|c|c|c|}
\hline Configuration & $\begin{array}{c}\text { Excess } \\
\text { Electricity } \\
(\mathbf{k W h} / \mathbf{y e a r})\end{array}$ & $\begin{array}{c}\text { Unmet } \\
\text { Electrical } \\
\text { load } \\
(\mathbf{k W h} / \mathbf{y e a r})\end{array}$ & $\begin{array}{c}\text { Capacity } \\
\text { Shortage } \\
(\%)\end{array}$ \\
\hline DG set only & 0 & 0 & $0 \%$ \\
\hline $\begin{array}{c}\text { DG set with } \\
\text { battery }\end{array}$ & $\begin{array}{c}0.0000813 \\
(0.00 \%)\end{array}$ & 0 & $0 \%$ \\
\hline $\begin{array}{c}\text { SPV/DG set } \\
\text { without battery }\end{array}$ & $\begin{array}{c}16929 \\
(23.2 \%)\end{array}$ & 0.0000396 & $0 \%$ \\
\hline $\begin{array}{c}\text { SPV/DG set } \\
\text { with battery }\end{array}$ & $\begin{array}{c}8279 \\
(12.8 \%)\end{array}$ & 0.0000453 & $0 \%$ \\
\hline
\end{tabular}

From Table 8, it is observed that the excess energy production of SPV/DG set with battery is $8279 \mathrm{kWh} /$ year (12.8\%) without any unmet load whereas it is $16929(23.2 \%)$ for SPV/DG set without battery, 0 for DG set only and 0.0000813 for DG set with battery respectively.

Further, the contribution of SPV and DG set independently and in combination for each month of the year of hybrid SPV/DG set with battery model is depicted in Figure 4-Figure 6.

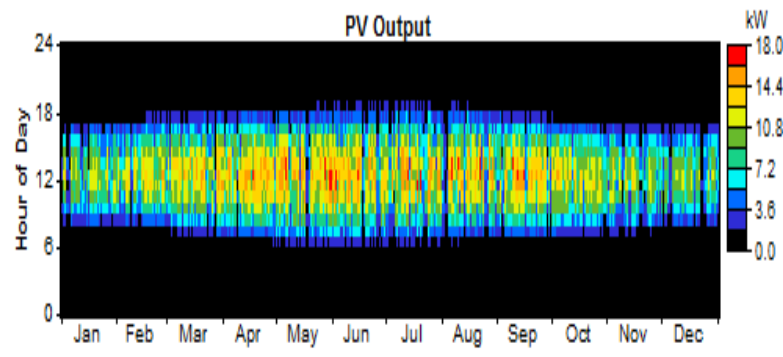

Fig. 4. Electricity production of SPV in SPV/DG with battery hybrid model 


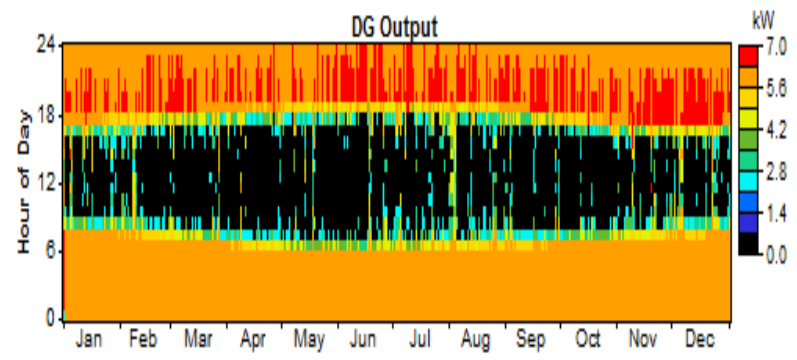

Fig. 5. Electricity production of DG set in SPV/DG with battery hybrid model

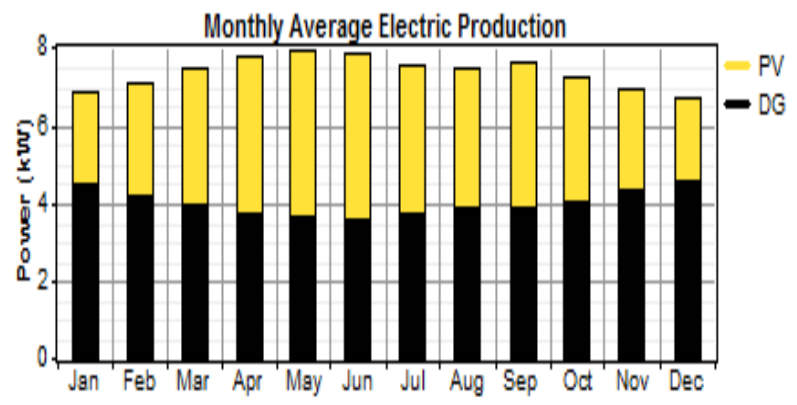

Fig. 6. Electricity production of hybrid SPV/DG with battery model

It is observed from Figure 6 that the energy production is high during May and low during December due to variation in solar irradiance.

\subsection{Sensitivity Analysis}

In the present study, the sensitivity analysis has been done to evaluate the performance of the proposed model by considering the diesel price and load demand as the sensitivity variables. This analysis has been conducted to study the variation of various parameters and their impacts on the selection of model. In addition, this analysis has been investigated the feasibility of hybrid SPV/DG with battery model at different values of load demand and diesel prices, as mentioned in Table 9.

Table 9. Different values of sensitivity variables

\begin{tabular}{|c|c|}
\hline Sensitivity Variable & $\begin{array}{c}\text { Different Values of } \\
\text { Sensitivity Variable }\end{array}$ \\
\hline Diesel price $(\$)$ & $0.600,0.650,0.700,0.750$, \\
$0.800,0.850$
\end{tabular}

The effect of variation in load demand and diesel price on COE, NPC, operating cost and annualized cost are depicted in Figure 7- Figure 10.

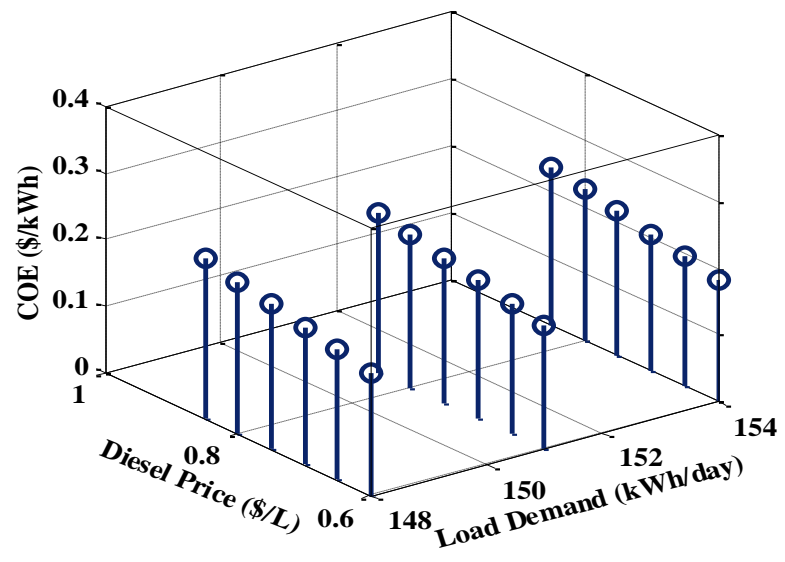

Fig. 7. Effect of variation of load demand and diesel price on COE

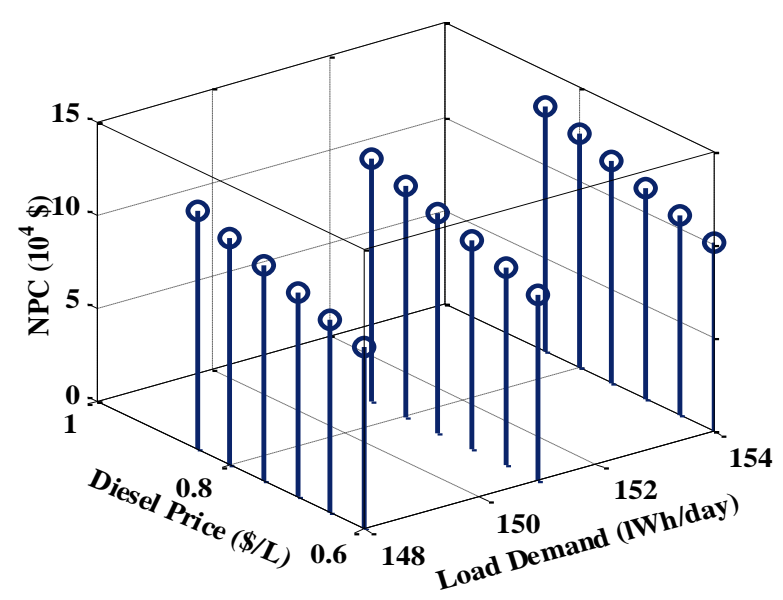

Fig. 8. Effect of variation of load demand and diesel price on NPC

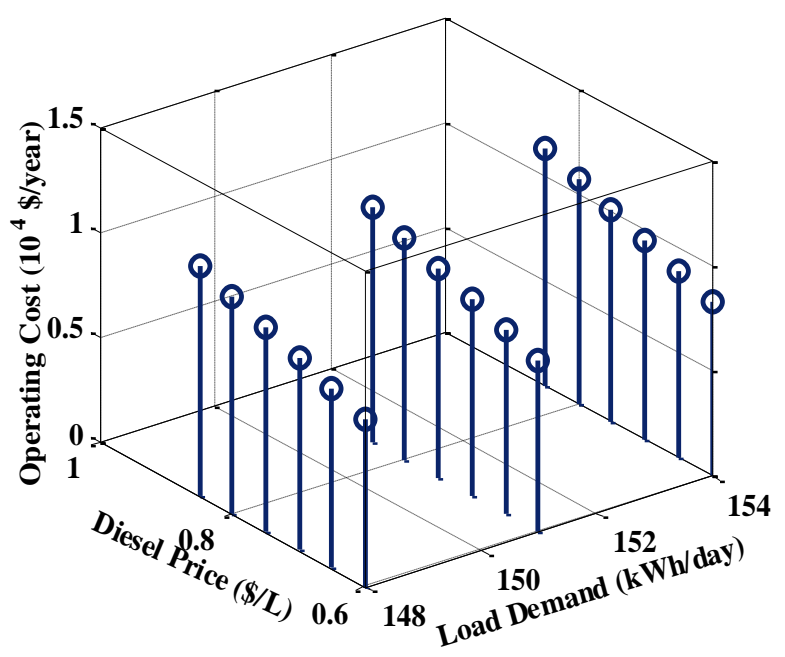

Fig. 9. Effect of variation of load demand and diesel price on operating cost 


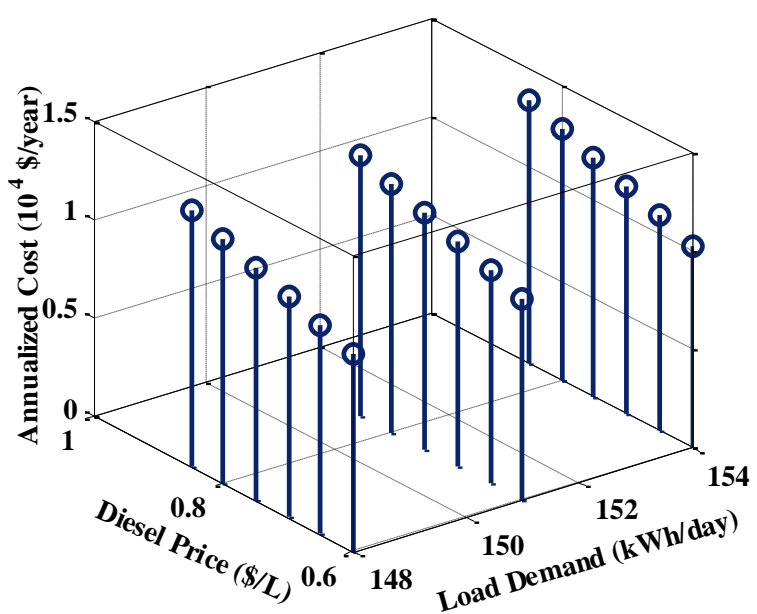

Fig. 10. Effect of variation of load demand and diesel price on annualized cost

From Figure 7- Figure 10, it is revealed that the COE, NPC, operating cost and annualized cost are increasing with increase in diesel price. It is further observed that the operating cost, NPC and annualized cost increases with the increase in load demand while the COE decreases. In addition, the result also shows that SPV/DG with battery hybrid model is still feasible and economical for lower and higher values of diesel prices and load demand.

\section{CONCLUSION}

In this paper, a sustainable and environment friendly hybrid model based on SPV/DG set with battery is proposed for reliable power supply to BTS. The model is selected on the basis of cost of energy and GHG emissions. The cost of energy from the proposed model is $\$ 0.217 / \mathrm{kWh}$ whereas it is $\$ 0.266 / \mathrm{kWh}$ from the existing diesel generator set. Further, the GHG emissions reduction is about $34 \%$ of the proposed model as compared to the existing system which is very significant.

Keeping in view of the above, hybrid model based on SPV/DG set with battery is proposed for the given remote location. The results of the proposed study revealed that the proposed hybrid system can be deployed to provide the cost effective electricity to the BTS load where no other renewable energy resources are available and exploitable. Further, the proposed model would also be helpful in achieving the target of Government of India "Power to all" and "Digital India" etc.

\section{ACKNOWLEDGMENT}

The first author would like to express gratitude to I.K. Gujral Punjab Technical University, Kapurthala, Jalandhar (Punjab) for providing research facilities for pursuing research work.

\section{ABBREVIATIONS AND SYMBOLS}

$\begin{array}{ll}\text { BTS } & \text { Base Transceiver Station } \\ \mathrm{CO} & \text { Carbon monoxide (Tonnes/year) } \\ \mathrm{COE} & \text { Cost of energy }(\$ / \mathrm{kWh}) \\ \mathrm{CO}_{2} & \text { Carbon dioxide (Tonnes/year) } \\ \mathrm{CDMA} & \text { Code division multiple axis } \\ \mathrm{DC} & \text { Direct current }\end{array}$

\begin{tabular}{ll} 
DG & Diesel generator \\
FC & Fuel cell \\
GSM & Global system for mobile communication \\
GW & Gigawatt \\
HOMER & Hybrid optimization model for electric renewable \\
NO $_{x}$ & Nitrogen oxide (Tonnes/year) \\
NPC & Net present cost (\$) \\
NREL & National renewable energy laboratory \\
O\&M & Operation and maintenance \\
PEM $^{2}$ & Proton exchange membrane (Tonnes/year) \\
PM $_{\text {SO }}$ & Particulate matter (Tonnes/year) \\
SPV & Sulphur dioxide (Tonnes/year) \\
UHC & Solar photovoltaic \\
\hline
\end{tabular}

Greek Symbols

$\begin{array}{ll}\$ & \text { Dollar } \\ \% & \text { Percentage }\end{array}$

\section{REFERENCES}

[1] Jain, A., Srinivas, E., Raman, S., Gaddam, R. R., Haritha, V. V. S. S., and Srinath, N. V. 2010. Sustainable energy plan for an Indian village. In Proceedings of IEEE Power System Technology, Hangzhou. 1-8.

[2] Ministry of New \& Renewable Energy, Government of India. www.mnre.gov.in.

[3] Kanse-Patil, A. B., Saini, R. P, and Sharma, M. P. 2010. Integrated renewable energy systems for off grid rural electrification of remote area. Renewable Energy. 35(6), 1342-1349.

[4] Setiawan, A. A., Zhao, Y., and Nayar, C. V. 2009. Design, economic analysis and environmental considerations of mini-grid hybrid power system with reverse osmosis desalination plant for remote areas. Renewable Energy. 34(2), 374-383.

[5] Akella, A. K., Sharma. M. P., and Saini, R. P. 2007. Optimum utilization of renewable energy sources in a remote area. Renewable and Sustainable Energy Reviews. 11(5), 894-908.

[6] Rajoriya, A., and Fernandez, E. 2010. Sustainable energy generation using hybrid energy system for remote hilly rural area in India. International Journal of Sustainable Engineering. 3(3), 219-227.

[7] Asrari, A., Ghasemi, A., and Javidi, M. H. 2012. Economic evaluation of hybrid renewable energy systems for rural electrification in Iran- a case study. Renewable and Sustainable Energy Reviews. 16(5), 3123-3130.

[8] Castellanos, J. G., Walker, M., Poggio, D., Pourkashanian, M., and Nimmo, W. 2015. Modelling an off-grid integrated renewable energy system for rural 
electrification in India using photovoltaics and anaerobic digestion. Renewable Energy. 74(2), 390-398.

[9] Al-Badi, A. H., and Bourdoucen, H. 2012. Study and design of hybrid diesel-wind standalone system for remote area in Oman. International Journal of Sustainable Energy. 31(2), 85-94.

[10] Rehman, S., and Al-Hadhrami, L. M. 2010. Study of a solar PV-diesel-battery hybrid power system for a remotely located population near Rafha, Saudi Arabia. Energy. 35, 4986-4995.

[11] Robbins, T., and Hawkins, J. M. 1997. Powering telecommunications network interfaces using photovoltaic cells and supercapacitors. In Proceedings of IEEE Telecommunications Energy, Melbourne. 523-528.

[12] Lehman, P. A., Chamberlin, C. E., Zoellick, J. I., and Engel, R. A. 2000. A photovoltaic/fuel cell power system for a remote telecommunications station. In Proceedings of IEEE Photovoltaic Specialists, Anchorage. 1552-1555.

[13] Bajpai, P., Prakshan, N. P., and Kishore, N. K. 2009. Renewable hybrid stand-alone telecom power system modeling and analysis. In Proceedings of IEEE TENCON, Singapore. 1-6.

[14] Nema, P., Nema, R. K., and Rangnekar, S. 2010. Minimization of green house gases emission by using hybrid energy system for telephony base station site application. Renewable and Sustainable Energy Reviews. 14(6), 1635-1639.

[15] Anand, P., Bath, S. K., and Rizwan, M. 2016. Feasibility analysis of Solar-Biomass based standalone hybrid system for remote area. American Journal of Electrical Power and Energy Systems. 5(6), 99-108.

[16] Nema, P., Nema, R. K., and Rangnekar, S. 2010. PVsolar/wind hybrid energy system for GSM/CDMA type mobile telephony base station. International Journal of Energy and Environment. 1(2), 359-366.

[17] Paudel, S., Shrestha, J. N., Neto, F. J., Ferrira, J. A. F., and Adhikari, M. 2011. Optimization of hybrid PV/Wind power system for remote telecom station. In Proceedings of IEEE Power and Energy Systems, Chennai. 1-6.

[18] Kusakana, K., and Vermark, H. J. 2013. Hybrid renewable power systems for mobile telephony base stations in developing countries. Renewable Energy. 51, 419-425.

[19] Anayochukwu, A. V., and Ndubueze, N. A. 2013. Potentials of optimized hybrid system in powering offgrid macro base transmitter station site. International Journal of Renewable Energy Research. 3(4), 861-871.

[20] Anayochukwu, A. V., and Nnene, E. A. 2013. Simulation and optimization of hybrid diesel power generation system for GSM base station site in Nigeria. Electronic Journal of Energy \& Environment. 1(1), 37-56.

[21] Amutha, W. M, and Rajini, V. 2015. Techno-economic evaluation of various hybrid power systems for rural telecom. Renewable and Sustainable Energy Reviews. 43, 553-561.

[22] Olatomiwa, L., Mekhilef, S., Huda, A. S. N., and Sanusi, K. 2015. Techno-economic analysis of hybrid PVdiesel-battery and PV-wind-diesel-battery power systems for mobile BTS: the way forward for rural development. Energy Science and Engineering. 3(4), 271-285.

[23] Alsharif, M. H., Nordin, R., and Ismail, M. 2015. Energy optimisation of hybrid off-grid system for remote telecommunication base station deployment in Malaysia. EURASIP Journal on Wireless Communications and Networking. 64, 1-15.

[24] Sawle, Y., and Gupta, S. C. 2015. A noval system optimization of a grid independent hybrid renewable energy system for telecom base station. International Journal of Soft Computing, Mathematics and control. $4(2), 49-56$

[25] Khan, M. J., Yadav, A. K., and Mathew, L. 2017. Techno economic feasibility analysis of different combinations of PV-Wind-Diesel-Battery hybrid system for telecommunication applications in different cities of Punjab, India. Renewable and Sustainable Energy Reviews. 76, 577-607.

[26] Shahzad, M. K., Zahid, A., Rashid, T. U., Rehan, M. A., Ali, and Ahmad, M. 2017. Techno-economic feasibility analysis of a Solar-Biomass off -grid system for the electrification of remote rural areas in Pakistan using HOMER software. Renewable Energy. doi: 10.1016/j.renene.2017.01.033.

[27] Priyanka, Bath, S. K., and Rizwan, M. 2017. Design and optimization of RES based standalone hybrid System for remote applications. In Proceeding of $8^{\text {th }}$ IEEE conference on Innovative Smart Grid Technologies (ISGT 2017) sponsored by IEEE Power and Energy Society (PES), Washington DC, USA. 1-5.

[28] Anand, P., Bath, S. K., and Rizwan, M. 2017. Design of Solar-Biomass-Biogas Based Hybrid System for Rural Electrification with Environmental Benefits. International Journal on Recent and Innovation Trends in Computing and Communication. 5 (6), 450 - 456.

[29] Solanki, C. S. 2012. Renewable Energy Technologies: A Practical Guide for Beginners. New Delhi: PHI learning private limited.

[30] National Renewable Energy Laboratory (NREL) www.nrel.gov/homer. 